\title{
Detection of vanC1 and vanC2 Genes in an Enterococcal Isolate and vanC Genes in non-Motile Enterococcus spp.
}

\author{
Ramin Mazaheri Nezhad Fard ${ }^{1, *}$; Mary D. Barton ${ }^{1}$; Michael W. Heuzenroeder ${ }^{2}$ \\ ${ }^{1}$ School of Pharmacy and Medical Sciences, Sansom Institute, University of South Australia, Adelaide, Australia \\ ${ }^{2}$ Microbiology and Infectious Diseases, Women's and Children's Hospital, University of Adelaide, Adelaide, Australia \\ ${ }^{*}$ Corresponding author: Ramin Mazaheri Nezhad Fard, School of Pharmacy and Medical Sciences, Sansom Institute, University of South Australia, Adelaide, Australia. Tel: +98- \\ 2161117055, E-mail: raminmazaheri@gmail.com
}

Received: September 9, 2014; Revised: September 23, 2014; Accepted: September 25, 2014

\begin{abstract}
Background: In recent decades, bacterial antibiotic resistance (especially in enterococci) has become a significant problem for human and veterinary medicine. One of the most important antibiotic resistances in enterococci, vancomycin resistance, is encoded by van gene family.

Objectives: The aim of this study was to investigate antibiotic resistance to vancomycin in enterococci and the genes responsible for this resistance.

Materials and Methods: Two-hundred and thirty enterococcal isolates from pigs (207 isolates), chickens (15 isolates) and humans (eight isolates) were phenotypically and genotypically tested for resistance to vancomycin by minimum inhibitory concentration (MIC) and polymerase chain reaction (PCR). The van genes were confirmed by gene sequencing.

Results: Of the total isolates, $19 \%$ were phenotypically resistant to vancomycin, while nearly $15 \%$ contained either vanC1 or vanC2 gene. One resistant E. casseliflavus isolate with pig origin ( $\mathrm{MIC}>8 \mu \mathrm{g} / \mathrm{mL})$ contained both $v a n \mathrm{C} 1$ and vanC2 genes. Furthermore, one $v a n C 1$ was found in a sensitive E. faecalis isolate of pig origin (MIC $\leq 4 \mu \mathrm{g} / \mathrm{mL}$ ) and one $v a n C 2$ in a resistant E. faecium isolate of chicken origin (MIC $>32 \mu \mathrm{g} / \mathrm{mL}$ ). These genes were not accompanied by other van genes. Other detected genes were vanA in $11 E$. faecium isolates of chicken origin (MIC $>32 \mu \mathrm{g} / \mathrm{mL}$ ). No vanB genes were found. Gene sequencing results showed $100 \%$ identity with GenBank reference genes.

Conclusions: The current report is the first report on the detection of vanC1 and vanC2 genes in one enterococcal species with pig origin. This report is important as it proves the horizontal transfer of various vanC genes to one species possibly due to the compatibility class of plasmids. Furthermore, detection of vanC genes in E. faecalis and E. faecium isolates is important as it suggests that resistance to vancomycin in non-motile enterococci can be encoded by several mechanisms.
\end{abstract}

Keywords:Enterococcus; Antibiotic Resistance; Vancomycin

\section{Background}

In recent decades, bacterial resistance to antibiotics has become a significant problem for patients and for medical and veterinary practitioners $(1,2)$. One group of these resistant bacteria, enterococci, is found among multiple-resistant opportunistic pathogens isolated from long-term hospitalized patients (3). These bacteria most commonly infect urogenital tract, bloodstream, endocardium, abdomen, pelvis, biliary tract, burn wounds and in-dwelling foreign devices (such as intravascular catheters) $(4,5)$. Less commonly, enterococci can infect central nervous system, lungs, soft tissues, paranasal sinuses, ears, eyes and periodontal tissues (6). One of the most important antimicrobials against enterococci is glycopeptide class of antibiotics. Glycopeptides such as vancomycin and avoparcin show bacteriostatic activity against a broad-spectrum of Gram-positive bacteria. Glycopeptides inhibit the biosynthesis of the major structural cell wall polymer, peptidoglycan, by forming bonds with the D-alanyl-D-alanine terminal of muramyl dipep- tides $(7,8)$. This mechanism of resistance to avoparcin is similar to that of vancomycin, both encoded by the "van" genes (9). The resistance is associated to both the antibiotics and the genetic determinants (genes) (10). Six types of vancomycin resistance genes are found in enterococci, including $\operatorname{van} \mathrm{A}, \operatorname{van} \mathrm{B}, \operatorname{van} \mathrm{C}, \operatorname{van} \mathrm{D}, \operatorname{van} \mathrm{E}$ and $\operatorname{van} \mathrm{G}(11,12)$. $\operatorname{van} \mathrm{A}, \operatorname{van} \mathrm{B}, \operatorname{van} \mathrm{D}$ and $\operatorname{van} \mathrm{E}$ are usually found in $\mathrm{E}$. fecalis and E. faecium and van $\mathrm{G}$ in E. fecalis. The vanC-encoded vancomycin resistance is restricted to motile entrococcal species, with a limited prevalence. Literature review shows no report on the presence of multiple vanC genes in an entrococcal species with pig origin. Furthermore, detection of vanC genes in E. fecalis and isolates is important as this suggests that resistance to vancomycin and avoparcin in non-motile enterococci can be encoded by several mechanisms.

\section{Objectives}

The aim of this study was to access antibiotic resistance

Copyright (C) 2014, Hamadan University of Medical Sciences; Published by Safnek. This is an open-access article distributed under the terms of the Creative Commons Attribution-NonCommercial 4.0 International License (http://creativecommons.org/licenses/by-nc/4.0/) which permits copy and redistribute the material just in noncommercial usages, provided the original work is properly cited. 
to two glycopeptide-type antibiotics in enterococci and the genes responsible for this resistance.

\section{Materials and Methods}

Two-hundred and thirty enterococcal isolates from pig (207 isolates including 80 E. faecalis, 71 E. faecium, 13 E. casseliflavus, 21 E. gallinarum, 17 E. hirae/durans, two E. hirae, one undefferintiated and two E. raffinosus), chicken (15 isolates including one E. faecalis and 14 E. faecium) and human (eight isolates including three E. faecalis, three E. faecium, one E. casseliflavus and one E. gallinarum) fecal specimens, collected by the University of South Australia and the Women's and Children's Hospital (WCH), Adelaide, were used in this study. Bacterial cultures were transferred into glycerol broth and stored at $-80^{\circ} \mathrm{C}$ for long-term maintenance. These bacteria were recovered by culturing on blood Columbia agar or tryptone soy agar (TSA) plates and overnight incubation at $37^{\circ} \mathrm{C}$ with $5 \% \mathrm{CO}_{2}$. All isolates had previously been identified to the species level using differential culture media and biochemical tests and in the case of E. faecalis and E. faecium, by species-specific PCR primers.

\subsection{Antibiotic Susceptibility Testing}

All enterococcal isolates were phenotypically tested for susceptibility to vancomycin and avoparcin (SigmaAldrich, USA) by minimum inhibitory concentration (MIC), according to the approved standard procedure of Clinical and Laboratory Standards Institute (CLSI) (13). This was carried out using agar dilution method. Results were interpreted based on the breakpoints published by CLSI and other authorities, including Danish Integrated Antimicrobial Resistance Monitoring and Research (DANMAP) (14), National Antimicrobial Resistance Monitoring System (NARMS) (15) and Norwegian Monitoring Program for Resistance in Microbes (NORM/NORMVET) (16). These well-established references were chosen when isolates from animal origin were tested, since CLSI mostly publishes breakpoints for human isolates. Briefly, various concentrations of the antibiotics were added to Mueller-Hinton agar media and poured into petri dishes. Then, a single colony of a pure culture on tryptone soy agar (TSA) was selected and suspended in sterile normal saline to a turbidity equivalent to $0.5 \mathrm{McF}$ arland. This suspension was diluted again 1:10 in sterile saline to make a final concentration of $107 \mathrm{cfu} / \mathrm{mL}$ and inoculated onto the Mueller-Hinton plates by a replicator. The inoculated plates were incubated at $35-37^{\circ} \mathrm{C}$ for $16-24$ hours and then were read.

\subsection{Molecular Identification}

\subsubsection{PCR Amplification of Resistance Genes}

Polymerase chain reaction (Single and Multiplex PCR) was used for the detection of antibiotic resistant genes in enterococci, using specific primers (Table 1 ). The generally modified protocol used for the PCR is given as follows: A few fresh enterococcal colonies on blood Columbia agar were suspended in $200 \mu \mathrm{L}$ of sterile distilled water. Bacterial cells were heated at $95^{\circ} \mathrm{C}$ for 20 minutes for DNA extraction. The mixture was then centrifuged at $7500 \mathrm{~g}$ for five minutes and the supernatant was collected. To prepare $25 \mu \mathrm{L}$ of master mix for each sample, $5 \mu \mathrm{L}$ of $5 \times$ PCR buffer, $1 \mu \mathrm{L}$ of $25 \mathrm{mM} \mathrm{MgCl}_{2}, 0.2 \mu \mathrm{L}$ of $25 \mathrm{mM}$ dNTPs, $1 \mu \mathrm{L}$ of each primer in $10 \mathrm{pmol}$ concentration and $0.2 \mu \mathrm{L}$ of $5 \mathrm{U} / \mu \mathrm{L}$ Taq DNA polymerase were mixed in a sterile microtube. Sufficient amount of sterile distilled water was added to this mixture to reach the total volume of $23 \mu \mathrm{L}$ and then 2 $\mu \mathrm{L}$ of the extracted DNA was added to the mixture (17). Following an initial denaturation at $95^{\circ} \mathrm{C}$ for three minutes, products were amplified by 30 cycles of denaturation at $95^{\circ} \mathrm{C}$ for 30 seconds, annealing at different temperatures for 30 seconds and extension at $72^{\circ} \mathrm{C}$ for one minute. Amplification was followed by a final extension at $72{ }^{\circ} \mathrm{C}$ for five minutes (18). PCR products were detected by electrophoresis in $1 \mu \mathrm{g} / \mathrm{mL}$ ethidium bromide-stained 1\% agarose gels in $0.5 \times \mathrm{TBE}$ buffer at $100 \mathrm{~V}$ for 90 minutes and then using visualizing technique under the UV light.

\begin{tabular}{|c|c|c|c|c|}
\hline Drug & Gene & Sequences $\left(5^{\prime} \rightarrow 3^{\prime}\right)$ & bp & Reference \\
\hline \multirow[t]{2}{*}{ AVO, VAN } & $\operatorname{van} \mathrm{A}$ & F: GGGAAAACGACAATTGC & 732 & (19) \\
\hline & & R:GTACAATGCGGCCGTTA & & \\
\hline \multirow[t]{2}{*}{ VAN } & $\operatorname{van} \mathrm{B}$ & F:ATGGGAAGCCGATAGTC & 635 & (19) \\
\hline & & R:GATTTCGTTCCTCGACC & & \\
\hline \multirow[t]{2}{*}{ VAN } & vanC1 & F:GGTATCAAGGAAACCTC & 822 & (19) \\
\hline & & R: CTTCCGCCATCATAGCT & & \\
\hline \multirow[t]{2}{*}{ VAN } & vanC2 & F: CTCCTACGATTCTCTTG & 439 & (19) \\
\hline & & R: CGAGCAAGACCTTTAAG & & \\
\hline
\end{tabular}

\footnotetext{
${ }^{a}$ AVO, Avoparcin; VAN, vancomycin.
} 


\subsubsection{Gene Sequencing}

Amplified DNA products from isolates with putative van genes were sequenced and the results were compared with GenBank and ExPASy genomic databases. Sequencing was carried out at the SouthPath Sequencing Facility (Flinders University, Adelaide) using Sanger method.

\section{Results}

Overall, most of the isolates were resistant to vancomycin (including 12 E. casseliflavus, 21 E. gallinarum and $12 \mathrm{E}$. faecium) and avoparcin (including one E. faecalis and $9 E$. faecium). No resistance to vancomycin was seen in human isolates. Of the total isolates, $6 \%$ were phenotypically resistant to avoparcin. Avoparcin resistant isolates included 11 E. faecium of chicken origin (MIC $\geq 32 \mu \mathrm{g} / \mathrm{mL}$ ) and one E. fecalis and one E. facium with human origin (MIC $\geq 16$ $\mu \mathrm{g} / \mathrm{mL}$ ). All avoparcin resistant isolates (except one E. faecalis and one E. faecium isolates of human origin) were from chickens (Table 2). Of the total isolates, 19\% were phenotypically resistant to vancomycin, while nearly $15 \%$ contained either van $\mathrm{C} 1$ or vanC2 gene. VanC1 was found in 22 isolates (10\%) (Including three E. casseliflavus, one E. faecalis and 18 E. gallinarum), vanC2 in 13 isolates (6\%) (including ten E. casseliflavus, one E. faecium and two E. gallinarum). One resistant E. casseliflavus isolate with pig origin (MIC $>8 \mu \mathrm{g} / \mathrm{mL}$ ) contained both van $\mathrm{C} 1$ and vanC2. Furthermore, one vanC1 was found in a sensitive E. faecalis isolate of pig origin (MIC $\leq 4 \mu \mathrm{g} / \mathrm{mL}$ ). No vanC1 was found in chicken isolates but one vanC2 E. faecium of chicken origin (MIC $>32 \mu \mathrm{g} / \mathrm{mL}$ ). No vanC2 gene was found in enterococcal isolates of human origin. vanA was found in 13 isolates (6\%) (including one E. faecalis and 12 E. faecium); all (except two) belonged to E. faecium of chicken origin. No vanB was found (Table 3). Nine resistant E. faecium isolates with chicken origin (MIC $\geq 32 \mu \mathrm{g} / \mathrm{mL}$ ), one resistant E. faecalis isolates with human origin (MIC $\geq 16 \mu \mathrm{g} / \mathrm{mL}$ ), one sensitive E. faecium isolate with human origin (MIC $\leq$ $8 \mu \mathrm{g} / \mathrm{mL}$ ) and two sensitive E. faecium isolates with chicken origin (MIC $\leq 8 \mu \mathrm{g} / \mathrm{mL}$ ) contained vanA gene within avoparcin resistant isolates. Sequencing of the detected genes showed at least 98\% identity with GenBank reference genes.

\begin{tabular}{|c|c|c|c|c|c|c|c|c|c|c|c|c|c|}
\hline \multirow[t]{2}{*}{ Drug } & \multicolumn{12}{|c|}{ No. of Isolates With MIC, $\mu \mathrm{g} / \mathrm{mL}$} & \multirow[t]{2}{*}{ Resistance, No. (\%) } \\
\hline & 1 & 2 & 4 & 8 & 12 & 16 & 20 & 32 & 64 & 128 & 512 & 1024 & \\
\hline \multicolumn{14}{|l|}{ Avoparcin } \\
\hline E.faecalis (84) & & & & 83 & & 1 & & & & & & & $1(1)$ \\
\hline E. faecium (88) & & & & 79 & & 1 & & 8 & & & & & $9(10)$ \\
\hline E.gallinarum (22) & & & & 22 & & & & & & & & & $0(0)$ \\
\hline E. casseliflavus (14) & & & & 14 & & & & & & & & & $0(0)$ \\
\hline E. hirae/durans (19) & & & & 16 & & & & & & & & & $0(0)$ \\
\hline E. raffinosus (2) & & & & 2 & & & & & & & & & $0(0)$ \\
\hline $\mathrm{N} / \mathrm{D}(1)$ & & & & 1 & & & & & & & & & $0(0)$ \\
\hline \multicolumn{14}{|l|}{ Vancomycin } \\
\hline E.faecalis (84) & & & 84 & & & & & & & & & & $0(0)$ \\
\hline E. faecium (88) & & & 76 & & & & & 12 & & & & & $12(14)$ \\
\hline E.gallinarum (22) & & & 1 & 21 & & & & & & & & & $21(95)$ \\
\hline E. casseliflavus (14) & & & 2 & 12 & & & & & & & & & $12(86)$ \\
\hline E. hirae/durans (19) & & & 19 & & & & & & & & & & $0(0)$ \\
\hline E. raffinosus (2) & & & 2 & & & & & & & & & & $0(0)$ \\
\hline $\mathrm{N} / \mathrm{D}(1)$ & & & 1 & & & & & & & & & & $0(0)$ \\
\hline
\end{tabular}

a $\mathrm{N} / \mathrm{D}$, not announced or applicable.

Table 3. Numbers of van Genes Detected by PCR ${ }^{a}$

\begin{tabular}{lcccc}
\hline Gene & Total $(\mathbf{n}=\mathbf{2 3 0})$ & Pig $(\mathbf{n}=\mathbf{2 0 7})$ & Chicken $(\mathbf{n}=\mathbf{1 5})$ & Human $(\mathbf{n}=\mathbf{8})$ \\
\hline vanA & $13(6)$ & $0(0)$ & $11(73)$ & $2(25)$ \\
vanB & $0(0)$ & $0(0)$ & $0(0)$ & $0(0)$ \\
vanC1 & $22(10)$ & $21(10)$ & $0(0)$ & $1(12)$ \\
vanC2 & $13(6)$ & $12(6)$ & $1(7)$ & $0(0)$ \\
\hline
\end{tabular}

${ }^{\mathrm{a}}$ Data are presented as No.(\%). 


\section{Discussion}

Vancomycin is of high importance to human medicine. Vancomycin has never been used in animal feed; therefore, all resistance to this antibiotic in chickens must be due to cross-resistance with avoparcin; both of which belong to the glycopeptides class of antibiotics (9). There are a few reports on vancomycin-resistant enterococcal isolates of animal origin. Furthermore, studies have shown a significant decrease in the prevalence of vancomycin resistance in Enterococcus spp. In Australia, Padiglione $(2000,2003)(20,21)$ is routinely used and molecular assays to assess the prevalence of vancomycin resistant enterococci(VRE). These studies suggested that a fecal colonization with VRE was present but uncommon in Australia. In the current study, 45 isolates (including 12 E. casseliflavus, 12 E. faecium and 21 E. gallinarum) with vancomycin resistance were investigated; of which, 12 were isolated from chickens. In chicken isolates, vancomycin resistance was detected more frequently in $E$. faecium than E. faecalis (12 instead of zero) $(\mathrm{P}<0.05)$ as reported by other researchers (22). Differences in results for vancomycin and avoparcin were found. In general, a low percentage (6\%) of resistance to avoparcin was detected; all in chicken with E. faecium (100\%), except one $E$. faecalis of human origin. This is not surprising because a similar difference has been reported in variety of papers. This might be seen due to a second mechanism for vancomycin resistance. Another reason for this difference could be the difference between MIC breakpoints, which are $\geq 8$ and $\leq 4 \mu \mathrm{g} / \mathrm{mL}$ for vancomycin and $\geq$ 6 and $<16 \mu \mathrm{g} / \mathrm{mL}$ for avoparcin, and also assessment of resistance/susceptibility of microorganisms with MICs close to breakpoint values. Avoparcin was used in Australian livestock (23), but has been banned since 2000 (24). A study carried out by Hart (2004) (25) showed no resistance to vancomycin or avoparcin in pig-related Enterococcal spp., two years after the ban of avoparcin use in Australian livestock. In a similar study carried out by Department of Agriculture, Fisheries and Forestry (DAFF) (26), no resistance to vancomycin was found in enterococci isolated from either pigs or chickens (except one chicken E. faecalis isolate with low-level resistance encoded by vanC) three years after the ban of avoparcin use in animal husbandry in Australia. The resistance to avoparcin in chicken isolates was possibly due to the previous use of avoparcin in animal husbandry $(7,8)$ and the fact that these isolates had been collected before the ban on use of avoparcin. However, the two other enterococcal species, E. casseliflavus and E. gallinarum, are known to be naturally resistant to vancomycin.

Relatively, vanC gene was found in intrinsically resistant E. casseliflavus and E. gallinarum, in accordance with previous studies. Seo (2005) (27) compared vancomycin resistance in 67 enterococcal isolates from poultry and pigs in Korea and found that vanC1 or $\operatorname{van} \mathrm{C} 2 / 3$ was associated with low-level resistance to vancomycin in E. gal- linaum, E. casseliflavus and E. flavescens isolates. Reports by Xavier (2006) (28), and Lemcke and Bulte (2000) (29) indicate the prevalence of van $\mathrm{C} 1$ and $v a n \mathrm{C} 2 / 3$ in enterococcal samples of pig and chicken origins; mostly vanC1 in $E$. gallinarum and vanC2/3 in E. casseliflavus. For example, Patel (1997) (30) detected vanC1 from one E. faecalis and one E. faecium strains; clinically isolated from humans. Only a low number of genes (13 vanA) encoding resistance to avoparcin was detected; all in chicken isolates. Use of avoparcin has been reported to be largely responsible for the amplification of vanA VRE in animals (31). Xavier (2006) (28) found no vanA or vanB in enterococci of poultry in Brazil. Similarly, Lemcke and Bulte (2000) (29) did not find van B in VRE enterococcal strains isolated from poultry and pork in Germany. However, they reported vanA in nearly half of the isolates. In the current study, 11 of vanA genes were found in E. faecium of chickens. Two vanA genes (one in E. faecalis and one in E. faecium) were also found in human isolates. Not surprisingly, vancomycin resistance was also seen in all chicken isolates resistant to avoparcin, carrying vanA. Although avoparcin was used in chickens - and to a lesser extent, pigs - before 2000, vanA was either not identified in E. faecium in their study or was reported in low numbers. E. faecium carrying vanB, the most commonly clinical VRE species in Australia, has been identified in healthy Australians (20, 21, 32). Similar findings were reported by Bell (1998) (33) and Burrell (2005) (34) in Adelaide and Melbourne, respectively. Moreover, Borhani et al. recovered 40 VRE isolates from an urban sewage treatment plant during 2009-2010 and reported that all the E. faecium isolates (100\%) harbored van $\mathrm{A}$ and five isolates (13\%) harbored both van A and $\operatorname{van} \mathrm{B}$ (35). In contrast, no vanB was found in the current study. The fact that vanB-type vancomycin resistance is not associated to the use of avoparcin in animals may explain the difference between the clinical and livestock isolates (19). In general, vancomycin resistant isolates were found in this study; mostly in E. faecium, E. gallinarum and E. casseliflavus. Furthermore, avoparcin resistant isolates were detected, mostly belonged to E. faecium. The encoding van genes (van $\mathrm{C} 1 / \mathrm{C} 2$ and $\operatorname{van} \mathrm{A})$ were reported in six to $10 \%$ of all isolates. This report is important as it proves the horizontal transfer of various vanC genes to one species possibly due to the compatibility class of plasmids. Furthermore, detection of vanC genes in E. faecalis and E. faecium isolates is important as it suggests that resistance to vancomycin in non-motile enterococci can be encoded by several mechanisms.

\section{Acknowledgements}

We wish to thank microbiology lab staff within the School of Pharmacy and Medical Sciences, University of South Australia.

\section{Authors' Contributions}

Study concept and design: Ramin Mazheri Nezhad Fard, 
Mary D. Barton, Michael W. Heuzenroeder. Acquisition of data: Ramin Mazheri Nezhad Fard, Analysis and interpretation of data: Ramin Mazheri Nezhad Fard, Drafting of the manuscript: Ramin Mazheri Nezhad Fard, Critical revision of the manuscript for important intellectual content: Mary D. Barton, Michael W. Heuzenroeder. Administrative, technical, and material support: Mary D. Barton, Michael W. Heuzenroeder. Study supervision: Mary D. Barton, Michael W. Heuzenroeder.

\section{Funding/Support}

This project was a part of a PhD thesis supported by the University of South Australia.

\section{References}

1. Larson E. Community factors in the development of antibiotic resistance. Annu Rev Public Health. 2007;28:435-47.

2. Levy SB, Marshall B. Antibacterial resistance worldwide: causes, challenges and responses. Nat Med. 2004;10(12 Suppl):S122-9.

3. Murray BE. Vancomycin-resistant enterococcal infections. N Engl JMed. 2000;342(10):710-21.

4. Wisell KT, Kahlmeter G, Giske CG. Trimethoprim and enterococci in urinary tract infections: new perspectives on an old issue. J Antimicrob Chemother. 2008;62(1):35-40.

5. Patel R, Rouse MS, Piper KE, Steckelberg JM. Linezolid therapy of vancomycin-resistant Enterococcus faecium experimental endocarditis. Antimicrob Agents Chemother. 2001;45(2):621-3.

6. Iaria C, Stassi G, Costa GB, Di Leo R, Toscano A, Cascio A. Enterococcal meningitis caused by Enterococcus casseliflavus. First case report. BMC Infect Dis. 2005;5(1):3.

7. Cooper EE. Antimicrobials: use in animal husbandry \& resistance in humans. AIC. 2000;5(1):16 -19.

8. Collignon PJ. Vancomycin-resistant enterococci and use of avoparcin in animal feed: is there a link? Med J Aust.1999;171(3):144-6.

9. Lu K, Asano R, Davies J. Antimicrobial resistance gene delivery in animal feeds. Emerg Infect Dis. 2004;10(4):679-83.

10. Levy SB. The 2000 Garrod lecture. Factors impacting on the problem of antibiotic resistance. $J$ Antimicrob Chemother. 2002;49(1):25-30

11. Domingo MC, Huletsky A, Giroux R, Picard FJ, Bergeron MG. vanD and vanG-like gene clusters in a Ruminococcus species isolated from human bowel flora. Antimicrob Agents Chemother. 2007;51(11):4111-7.

12. Fraimow H, Knob C, Herrero IA, Patel R. Putative VanRS-like twocomponent regulatory system associated with the inducible glycopeptide resistance cluster of Paenibacillus popilliae. Antimicrob Agents Chemother. 2005;49(7):2625-33.

13. Clinical Laboratory Standards Institute.. Methods for Dilution Antimicrobial Susceptibility Tests for Bacteria that Grow Aerobically: Approved Standard. 7 ed: Wayne; 2008.

14. Wikler MA, Clinical, Laboratory Standards Institute . Methods for Dilution Antimicrobial Susceptibility Tests for Bacteria that Grow Aerobically: Approved Standard.: National Committee for Clinical Laboratory Standards; 2009.

15. The National Antimicrobial Resistance Monitoring System . Human Isolates Final Report.: NARMS website; 2004.

16. The Norwegian Monitoring Programme for Antimicrobial Resistance. Usage of antimicrobial agents and occurrence of antimicrobial resistance in Norway:: NORM/NORM-VET web site; 2004.
17. Hartman AB, Essiet, I, Isenbarger DW, Lindler LE. Epidemiology of tetracycline resistance determinants in Shigella spp. and enteroinvasive Escherichia coli: characterization and dissemination of tet(A)-1.J Clin Microbiol. 2003;41(3):1023-32.

18. Jackson CR, Fedorka-Cray PJ, Barrett JB. Use of a genus- and species-specific multiplex PCR for identification of enterococci. $J$ Clin Microbiol. 2004;42(8):3558-65.

19. Dutka-Malen S, Evers S, Courvalin P. Detection of glycopeptide resistance genotypes and identification to the species level of clinically relevant enterococci by PCR. J Clin Microbiol. 1995;33(1):24-7.

20. Padiglione AA, Grabsch EA, Olden D, Hellard M, Sinclair MI, Fairley CK, et al. Fecal colonization with vancomycin-resistant enterococci in Australia. Emerg Infect Dis. 2000;6(5):534-6.

21. Padiglione AA, Wolfe R, Grabsch EA, Olden D, Pearson S, Franklin $\mathrm{C}$, et al. Risk factors for new detection of vancomycin-resistant enterococci in acute-care hospitals that employ strict infection control procedures. Antimicrob Agents Chemother. 2003;47(8):2492-8.

22. Tenover FC, McDonald LC. Vancomycin-resistant staphylococci and enterococci: epidemiology and control. Curr Opin Infect Dis. 2005;18(4):300-5.

23. Barton M, Wilkins J. Antibiotic resistance in bacteria isolated from poultry. Record of Rural Industries Research and Development Corporation Publication No 1/105. RIRDC Project No USA-9A website.; 2001.

24. National Drugs and Poisons Schedule Committee . Record of the Reasons Meeting 37.: NDPSC website; 2003.

25. Hart WS, Heuzenroeder MW, Barton MD. Antimicrobial resistance in Campylobacter spp., Escherichia coli and enterococci associated with pigs in Australia. J Vet Med B Infect Dis Vet Public Health. 2004;51(5):216-21.

26. Australian Government Department of Agriculture FAF. Pilot Surveillance Program for Antimicrobial Resistance in Bacteria of Animal Origin:DAFF,.: Department of Agriculture, Fisheries and Forestry; 2007.

27. Seo KS, Lim JY, Yoo HS, Bae WK, Park YH. Comparison of vancomycin-resistant enterococci isolates from human, poultry and pigs in Korea. Vet Microbiol. 2005;106(3-4):225-33.

28. Batista Xavier D, Moreno Bernal FE, Titze-de-Almeida R. Absence of VanA- and VanB-containing enterococci in poultry raised on nonintensive production farms in Brazil. Appl Environ Microbiol. 2006;72(4):3072-3.

29. Lemcke R, Bulte M. Occurrence of the vancomycin-resistant genes van $\mathrm{A}$, van $\mathrm{B}$, vanCl, vanC2 and vanC3 in Enterococcus strains isolated from poultry and pork. Int J Food Microbiol. 2000;60(2-3):185-94.

30. Patel R, Uhl JR, Kohner P, Hopkins MK, Cockerill FR, 3rd. Multiplex PCR detection of vanA, vanB, vanC-1, and vanC-2/3 genes in enterococci.JClin Microbiol.1997;35(3):703-7.

31. Ferguson JK. Vancomycin-resistant enterococci: causes and control. Med J Aust. 1999;171(3):117-8.

32. Schooneveldt JM, Marriott RK, Nimmo GR. Detection of a vanB determinant in Enterococcus gallinarum in Australia. J Clin Microbiol. 2000;38(10):3902.

33. Bell JM, Paton JC, Turnidge J. Emergence of vancomycin-resistant enterococci in Australia: phenotypic and genotypic characteristics of isolates. JClin Microbiol. 1998;36(8):2187-90.

34. Burrell LJ, Grabsch EA, Padiglione AA, Grayson ML. Prevalence of colonisation with vancomycin-resistant enterococci (VRE) among haemodialysis outpatients in Victoria: implications for screening. Med J Aust. 2005;182(9):492.

35. Borhani K, Ahmadi A, Rahimi F, Pourshafie MR, Talebi M. Determination of Vancomycin Resistant Enterococcus faecium Diversity in Tehran Sewage Using Plasmid Profile, Biochemical Fingerprinting and Antibiotic Resistance. JundishapurJMicrobiol. $2014 ; 7(2)$. 